\title{
THE USE OF OPERATIONAL CASH FLOW IN THE ESTIMATION OF ACCRUAL-BASED EARNINGS MANAGEMENT
}

\author{
Michal Comporek \\ University of Lodz, Lodz, Poland \\ e-mail: michal.comporek@uni.lodz.pl \\ ORCID: 0000-0002-1402-2505 \\ (C) 2019 Michał Comporek \\ This is an open access article distributed under the Creative Commons Attribution-NonCommercial- \\ -NoDerivs license (http://creativecommons.org/licenses/by-nc-nd/3.0/)
}

DOI: $10.15611 /$ fins.2019.2.04

JEL Classification: G30, M41, M42

\begin{abstract}
One of the most important analytical spheres enabling the diagnostic estimation of intentional changes in a company's financial result is the area of accrual adjustments of net profit, separated in the cash flow statement prepared using the indirect method. The special cognitive value of accrual differences can be seen when the structure of total accruals is separated by those adjustments that are not directly related to the real activity of the enterprise, and are the result of subjective accounting choices. The main objective of the article is to present the selected econometric models used for examining accrual-based earnings management phenomenon in Poland. The analysis includes following regression models, namely: the Jones model, the Kasznik model, the Dechow-Dichev model and the McNichols model. The empirical studies were conducted among listed companies qualified for the Warsaw Stock Exchange indices: WIG-20 and mWIG-40, whose shares were traded for at least ten years in 1998-2017.
\end{abstract}

Keywords: accrual-based earnings management, operational cash flow, net income, regression models.

\section{Introduction}

Modern scientific research relating to the measurement of the degree of implemented practices in the field of earnings management in an enterprise (based on adopted accounting policies and estimates) is mainly based on the use of statistical methodology, allowing the separation of two basic groups of accruals. The first of them is the so-called non-discretionary (operational) accruals $(N D A C C)$, referring to the specifics of business activity and being an expression of economic events occurring in the enterprise (e.g. investments made in fixed and current assets, or generated sales etc.). The second of these groups, is the discretionary accruals (DACC), assuming the summary effect of accounting choices in the field of "artificial" interference in the value of net profit (loss). 
Starting from 1991, when Jones for the first time presented the possibility of extracting non-discretionary and discretionary accrual by means of regression analysis, econometric models have become one of the most important analytical tools used to assess the scale of earnings management in business entities [Jones 1991 pp. 193-228]. The literature on the subject emphasizes that by supporting the process of detecting potential accounting manipulations at an early stage of control, these models limit the risk of missing fraud and irregularities related to specific accounting entries included in the entity's financial statements. At the same time, being an integral part of the analytical procedures used to detect the intentional shaping of the financial result of an economic entity, econometric models may prove helpful in highlighting significant differences in the actual and forecasted values of individual reporting items and in underlying those relationships that are inconsistent with other related accounting entries [Micherda, Szulc 2008, pp. 28-29].

The paper aims to present the selected econometric models used for examining accrual-based earnings management phenomenon in Poland. The main research optics has been directed towards the closer characterization of the Kasznik model, the Dechow-Dichev model and the McNichols model. Their further comparison with the original version of the Jones model can be used to ask the following research question: - of whether econometric models based on operating cash flow are characterized

by a higher degree of matching is an empirical date compared to the original version of the Jones model?

The study assumes that the attribute of operational cash flows, allowing for the elimination of the effects of various accounting entries of the same transactions or economic events, may strengthen the predictive power of these models (compared to the original version of the Jones model) and create a new area of measurement and comparisons of enterprise's economic achievements.

Bearing in mind the structure of the article, the first chapter presents the theoretical background pertaining to the problem of accrual-based earnings management together with a detailed presentation of the character of the tested regression models. The third chapter presents the results of empirical research relating to: the goodness-of-fit to the empirical data of selected regression models used to extracting of diversified subcategories of accrual-based earnings management, descriptive statistics of individual categories of discretionary accruals and the interrelations between the differentiated categories of discretionary accruals. Chapter 4 is a summary and discussion of the main findings of the conducted research.

\section{Theoretical background}

\subsection{Accruals based earnings management - its definition and scope}

In a narrower approach, accruals based earnings management occurs when managers use judgment in financial reporting and in structuring transactions to alter financial 
reports to either mislead stakeholders about the underlying economic performance of the company, or otherwise to influence contractual outcomes that depend on reported accounting numbers [Healy, Wahlen 1999, p. 368]. This perspective emphasizes the negative aspects of shaping the company's financial results, characterized in the literature as "black earnings management". A similar view of the issues raised can also be found in scientific works by Schipper, who identifies earnings management with "a purposeful intervention in the external financial reporting process, with the intent of obtaining some private gain", stressing low incentives with achieving private benefits at the forefront as a motivation of actions aimed at manipulating the value of the reported financial result [Schipper 1989, p. 92]. On the other hand, accrual based management may boil down to the use of flexibility in the selection of accounting procedures that have an impact on the reported result which may be of a positive nature (so-called "green earnings management") and neutral (so-called "white earnings management") [Ronen, Yaari 2008, pp. 20 and the following].

In many cases, it is difficult to clearly classify a specific method of earnings management to any of the indicated groups. The shaping of the financial result may be strictly dependent on the personal needs of the persons managing the entity, as well as the needs of the enterprise, understood as an organization separate from its owners. Looking at the wide range of accounting practices that leave interference in the value of the reported financial result, one should point to the quite extensive spectrum of techniques allowing for the fictitious increase or decrease of net profit (loss). In general, the mentioned techniques can be classified into a group of targeted actions or directly manipulating the values of the generated revenues and costs of an enterprise, or to a group of practices indirectly affecting the financial result of a business entity [Kutera et al. 2006, pp. 57-58]. Below we present a list of the most referenced accounting methods for deliberately distorting the entity's financial result. The following techniques were included in them, namely:

- premature recognition of revenues (e.g. sending products before the contract is finalized, recognizing revenues at the moment of uncertainty about their actual acquisition, recognition of sales revenues also in the part in which there is a high probability that it will be returned; recognition of revenues from services in the current period, in a situation in which they will be provided in subsequent periods, etc.);

- sales with a buy-back clause;

- incorrect capitalization costs (e.g.: costs of the current period are recognized as costs subject to settlement in time; including actual costs in asset items and their permanent exclusion outside the cost circle);

- failure to update the value of receivables whose collectability is questionable;

- manipulating expenditures on improvements in fixed assets;

- using transfer prices (as one of the methods of tax avoidance that results in the transfer of income between the branches creating an enterprise); 
- faulty presentation of the value of development costs (in particular, confirmation of the occurrence of conditions under which the costs of completed successful development activities incurred by the unit for its own needs before production or the real application of technology are included in the value of intangible assets);

- valuation of inventories in net selling prices in a situation where they have lost their economic usefulness for the entity;

- incorrect presentation of periods of use of fixed assets (property, plant and equipment; intangible assets; long-term investments including property) that are subject to depreciation;

- a biased failure to create reserves (provisions) despite the obligation on the entity; creating "fictitious" reserves (provisions); unjustified resolving of reserves (provisions) in a situation where it is unnecessary but convenient for the enterprise; concealing a portion of reserves (provisions) in the form of contingent liabilities;

- faulty depiction of leasing.

\subsection{Cash flow statement and its reference to accrual-based earnings management}

The cash flow statement provides users of financial reports with information qualitatively different from accounting entries derived from the balance sheet and the profit and loss account. It reflects the effects of the processes taking place in an enterprise in the form of receipts and payments, and thus more realistically presents the company's financial standing [Śnieżek, Wiatr 2011, p. 37]. Expertise relating to the amount of cash flows generated by the business entity in the results of its operations, as well as the structure of receipts and payments allows not only for the assessment of the quality of accrual net profit (loss) revealed in the income statement. The advantages sent from analyzing the cash flows area are much more, the most important of them focus on such issues as [Ijiri 1975, p. 35; Gos 2010, pp. 59-69]:

- cash flows can be considered as a "hard" economic measure, because the mensuration result does not depend on the adopted accounting assumptions and should be identical (or at least similar) regardless of the person effecting the measurement;

- cash flow statement is relatively the most difficult element to falsify in the financial report;

- current net cash flow gives a better insight and a broader view of receipts and payments from various activities of the company than accounting profits (loss), limited to results from operations;

- cash flow statement facilitates comparing the financial information of different entities because it eliminates the effects of applying different solutions and estimates in accounting for the same transactions and events;

- preparing cash flow statements enables to verify cash flow forecasts in the past, as well as to evaluate the relationship between profit (loss) and cash flows; 
- income statement does not directly disclose information about settlements with owners (own contributions and withdrawals, dividends, share trading etc.), whereas the cash flow statement exposes the mentioned information .

The properties of the presented cash flow statement theoretically allow for treating it as an objective category and resistant to the impact of accounting policy.

What is worth emphasizing is that relatively few techniques referring to the accruals based earnings management issue and reported in the previous subsection of the article are strictly related to the sphere of shaping the value of cash inflows and outflows in the enterprise ${ }^{1}$. The question then arises of whether the cash flow area is really freed from all accounting manipulations? As Schilit and Perler note [2010, p. 190], economic theory recognizes at least the following methods to manipulate cash flow statement, namely:

- transferring cash inflow from financing activities to inflow from operating activities;

- transferring cash outflow from operating activities to outflow from investing

- activities;

- increase in cash flow from operating activities using acquisition of part or all of the company;

- increase in cash flow from operating activities using the additional "ancillary" activities ${ }^{2}$.

These techniques are based primarily on creativity in the selection of the available accounting solutions, which, according to the information producer, will contribute to the better capturing and measurement of the economic events and their presentation in the financial statements in the manner that is in the best interest of the producer of this information. Confirmation of their wide application in business practice can be found also in scientific research by Mulford and Comiskey [2005, pp. 81-158], who cited numerous examples of financial statements in which the cash flows have been recorded in a way that could mislead the recipient of the financial information. These researchers have empirically shown that the subject of manipulation becomes a presentation of individual sources of inflows and payments. Megan et al. [2009, pp. 131-136] proved that about $33 \%$ of the analyzed enterprises try to "manage the expenses" and capitalize them in order to transfer cash out from operating activity to investing activity. Negrea et al. [2011, pp. 600-601] stated further that creative

${ }^{1}$ It should be noted that any manipulation on income and expenses directly or indirectly affects cash inflows and outflows. Time mismatch between income and expense recognition transactions, on the one hand, and collection of receivables from customers and payment of liabilities to suppliers and creditors, on the other hand, can lead to a dilemma regarding classification of cash flows [Arsenijević, Dukić 2017, p. 67].

${ }^{2}$ The considerations do not include those techniques of influencing the level of inflows (outflows) that are related to the problem of real earnings management (e.g. price discounts to temporarily increase sales, overproduction to report lower cost of goods sold, and a reduction of discretionary expenditures to improve reported margins) [Arsenijević, Dukić 2017, pp. 163-173]. 
accounting practices involve the presentation in the cash flow statement of received and paid dividends and interest, cash flows from the sale of receivables, one-off inflows and expenditure and recognition as part of the operating activities of the proceeds concerning de facto investing activities or financial activities. Eventually, Megan et al. [2009, pp. 508-513] added on to a set of accounting earnings management techniques in the cash flow statement: writing out company cheques late and using overdrafts, selling accounts receivables or the capitalization of expenses.

In conclusion, two issues should be emphasized. Firstly, the cash flow statement is a very important element of the financial report, verifying the accrual net profit (loss) and showing its monetary quality at a given time. Secondly, although it is potentially the most resistant to any accounting manipulation section of financial statement, the matter of earnings management also applies in relation to it.

\subsection{Characteristics of models used to separate individual categories of accruals}

The amount of total accruals $T A C C$ is the difference between the net income in a given year computed by using the accrual-based accounting system and the surplus in cash from operating activities. Its value rises as a result of the accrual-basis record of all non-cash and cash economic events, which allows management a certain degree of freedom in the subjective creation of an image of the company's financial results [Comporek 2018, p. 23]. This assumption may be represented by the following equation:

$$
T A C C_{t}=E A T_{t}-O C F_{t},
$$

where: $T A C C_{t}-$ total accruals in year $t$;

$O C F_{t}$ - operating cash flows in year $t$;

$E A T_{t}$ - earnings after taxes in year $t$.

As was previously indicated, an attempt to estimate the scale and directions of earnings management implies the necessity of decomposing the total accruals (TACC) into two parts, i.e. the "normal" accruals, referring to operational activities and those expected to be caused by the factors, including the use of selected methods and accounting estimates to manipulate the demonstrated net profit (loss) (DACC). The correct extraction of the said sub-categories of accruals should take into account the need to draw attention to the fact that the value of the TACC indicator calculated for a given enterprise should not be directly compared to the value of adjustments reported by other business entities. This postulate stems from the fact that business entities operating on a larger scale (or in different branch of industry) can show higher values of accruals. For this reason, in order to maintain data comparability, the values of variables included in the earning management models should be standardized (usually it is based on the inclusion of endo- and exogenous variables in relation to the total assets of the enterprise). 
The original Jones model assumes that the value of non-discretionary accruals is determined by two variables, which include: change in sales revenues and average value of property, plant and equipment [Jones 1991, pp. 193-228]. On the other hand, the value of discretionary accruals is based on the difference between the empirical and theoretical value of the TACC as the explained variable:

$$
\frac{T A C C_{t}}{T A_{t-1}}=\underbrace{\alpha_{1}\left(\frac{1}{T A_{t-1}}\right)+\alpha_{2}\left(\frac{\Delta R E V_{t}}{T A_{t-1}}\right)+\alpha_{3}\left(\frac{P P E_{t}}{T A_{t-1}}\right)}+\underbrace{\varepsilon_{t},}
$$

where: $T A_{t-1} \quad-$ average value of total assets from year $t-1$;

$\triangle R E V_{t}$ - change in sales revenues in year $t$

$P P E_{t} \quad-$ average value of property, plant and equipment in year $t$;

other designations - as above.

The modified version of the Jones model, developed by Kasznik, explains any changes in the value of total accruals by using such predicators as: the difference between change in sales revenues and change in short-term receivables, the average value of property, plant and equipment and the increase in operating cash flows [Kasznik 1999, pp. 57-81]. In this way, the form of the regression model, allowing the separation of individual categories of accrual differences, took the following form:

$$
\frac{T A C C_{t}}{T A_{t-1}}=\underbrace{\alpha_{1}\left(\frac{1}{T A_{t-1}}\right)+\alpha_{2}\left(\frac{\Delta R E V_{t}-\Delta \mathrm{REC}_{\mathrm{t}}}{T A_{t-1}}\right)+\alpha_{3}\left(\frac{P P E_{t}}{T A_{t-1}}\right)+\alpha_{4}\left(\frac{\Delta O C F_{t}}{T A_{t-1}}\right)}_{\begin{array}{c}
\text { non-discretionary accruals } \\
N D A C C_{\text {Kasznik }}
\end{array}}+\underbrace{\varepsilon_{t}}_{\begin{array}{c}
\text { discretionary accruals } \\
D A C C_{\text {Kasznik }}
\end{array}}
$$

where: $\triangle \mathrm{REC}_{\mathrm{t}}-$ change in trade receivables in year $t$;

$\triangle O C F_{t}$ - change in operation cash flow in year $t$ relative to year $t-1$; other designations - as above.

Both the Jones model and the Kasznik model refer to the extractions of individual subcategories of accruals in a holistic approach. However, accruals can also be classified into two other categories: current accruals that reflect the current shortterm differences that affect the working capital account and defined as changes in current accounts, excluding accounts which are not reflected in measuring of interest 
$(C A C C)$ or non-current accruals that derive from the difference between total accruals and current accruals $(N C A C C)$. This item has a long-term nature and does not affect working capital account [Hosseinimehr, Nourifard 2014, p. 93]. This assumption can be characterized by the following calculation formula:

$$
\text { TACC }_{t}=\text { CACC }_{t}+N C A C C_{t},
$$

where: $C A C C_{t}-$ current accruals of company in year $t$;

$N C A C C_{t}-$ non-current accruals of company in year $t$; other designations - as above.

Two further regression models used in the research using the category of operating cash flows in their analytical formulas are used only to distinguish discretionary working-capital accruals. Thus, the Dechow and Dichev model examines short-term earnings management as the relationship between accruals and operational cash flows, wherein earnings quality is represented by the standard deviation of residuals [Dechow, Dichev 2002, pp. 35-59]:

$$
\begin{aligned}
& \frac{C A C C_{t}}{T A_{t-1}}=\underbrace{\alpha_{1}\left(\frac{1}{T A_{t-1}}\right)+\alpha_{2}\left(\frac{O C F_{t-1}}{T A_{t-1}}\right)+\alpha_{3}\left(\frac{O C F_{t}}{T A_{t-1}}\right)+\alpha_{4}\left(\frac{O C F_{t+1}}{T A_{t-1}}\right)}+\underbrace{\varepsilon_{t},} \\
& \text { non-discretionary current } \\
& \text { accruals } N D C A C C_{\text {Dechow }}
\end{aligned}
$$

In turn, the McNichols model is a kind of integrated methodological approach developed by Jones [1991] and Dechow, Dichev [2002]. It is possible to visualize considering the fact that its computational formula [McNichols 2002, pp. 61-69]:

$$
\frac{C A C C_{t}}{T A_{t-1}}=\underbrace{\alpha_{1}\left(\frac{1}{T A_{t-1}}\right)+\alpha_{2}\left(\frac{\Delta R E V_{t}}{T A_{t-1}}\right)+\alpha_{3}\left(\frac{P P E_{t}}{T A_{t-1}}\right)+\alpha_{4}\left(\frac{O C F_{t-1}}{T A_{t-1}}\right)+\alpha_{5}\left(\frac{O C F_{t}}{T A_{t-1}}\right)+\alpha_{6}\left(\frac{O C F_{t+1}}{T A_{t-1}}\right)}_{\begin{array}{l}
\text { non-discretionary current } \\
\text { accruals } N D C A C C_{M c N i c h o l s}
\end{array}}+\varepsilon_{t}
$$

\section{Results of empirical research}

\subsection{Research sample and methodology}

The empirical studies presented in the article were conducted among listed companies qualified for the Warsaw Stock Exchange indices: WIG-20 and mWIG-40 (as at 31 August 2018), whose shares were traded for at least ten years in the adopted reference horizon of 1998-2017. In this way, it became possible to distinguish enterprises which in their assumption significantly differentiated: objects of production or 
service activities, the nature of the supply and sales market, technical equipment, etc. Additionally, a sample selection was based on the following criteria:

- the fiscal year of firm should be end by 31 December;

- companies do not conduct business activity in the finance and insurance sectors;

- all the required financial data must be available.

The reference base of the research were the annual unit financial reports taken from the Notoria Serwis SA database.

Research methodology refers to the presentation of statistics for the goodness-offit of selected accruals based on models computed by OLS regression and descriptive statistics of individual categories of discretionary accruals, extracting by the Kasznik model, the Dechow-Dichev model or the McNichols model. In-depth empirical studies have been focused around the values of correlations calculated by the Pearson correlation coefficient. This measure was used to compute the intensity and direction of relationships between the four categories of discretionary accruals separated by the mentioned econometrics models. In the paper the following interpretation of calculated correlation coefficients should be adopted, namely:

- $r=0-$ no correlation,

- $0<|r|<0.2$ - practically no linear correlation between the examined variables,

- $0,2 \leq|r|<0.4$ - linear correlation clear, but low,

- $0,4 \leq|r|<0.7$ - moderate correlation,

- $0,7 \leq|r|<0.9$ - significant correlation,

- $|r| \geq 0.9$ - correlation very strong,

- $|r|=1-$ full correlation [Ostasiewicz et al. 2001, p. 311].

\subsection{Goodness-of-fit of accrual-based models used for the detection of earnings management}

The first step of the evaluation of research aptitude of accrual-based models was associated with the attempt to estimate the degree of matching to the empirical data of individual econometric models considered in the research. In order to know whether accrual-based models can statistically explain the phenomenon of earnings management, different regression analyses were performed (see Table 1 and Table 2).

The results of the research indicate that the goodness-of-fit of accrual-based models varies considerably between the examined models. For the originally performed Jones model the studies showed a high percentage of observations with very poor fitting and, on the other hand, the lowest percentage of observations with very good matching to the empirical data (respectively: $30.56 \%$ and $2.78 \%$ ), which underlines that the exploited regressors, such as sales revenues $(\triangle R E V)$ and plant, property and equipment $(P P E)$ are not powerful enough at predicting or explaining the values of the dependent variable in the sample of data at hand. However, by including in the model's analytic formula such exogenous variables as receivables $(\triangle R E C)$ and (especially) operation cash flow $(\triangle O C F)$, it has become possible to 
Table 1. Statistics for the goodness-of-fit of accrual based models computed by OLS regression

\begin{tabular}{|l|c|c|c|c|c|}
\hline \multirow{2}{*}{ Model } & \multicolumn{5}{|c|}{ Goodness-of-fit of the model } \\
\cline { 2 - 6 } & $\begin{array}{c}\text { Very poor fit } \\
\left(\text { Adj. } R^{2}<0\right)\end{array}$ & $\begin{array}{c}\text { Poor fit } \\
\left(0 \leq \mathrm{Adj} . R^{2}<0,2\right)\end{array}$ & $\begin{array}{c}\text { Average fit } \\
\left(0,2 \leq \mathrm{Adj} . R^{2}<0,4\right)\end{array}$ & $\begin{array}{c}\text { Good fit } \\
\left(0,4 \leq \mathrm{Adj} . R^{2}<0,6\right)\end{array}$ & $\begin{array}{c}\text { Very good fit } \\
\left(\text { Adj. } R^{2} \geq 0,6\right)\end{array}$ \\
\hline Jones & $30.56 \%$ & $13.89 \%$ & $36.11 \%$ & $16.67 \%$ & $2.78 \%$ \\
\hline Kasznik & $13.89 \%$ & $19.44 \%$ & $19.44 \%$ & $22.22 \%$ & $25.00 \%$ \\
\hline $\begin{array}{l}\text { Dechow, } \\
\text { Dichev }\end{array}$ & $41.67 \%$ & $33.33 \%$ & $13.89 \%$ & $5.56 \%$ & $5.56 \%$ \\
\hline McNichols & $30.56 \%$ & $25.00 \%$ & $19.44 \%$ & $16.67 \%$ & $8.33 \%$ \\
\hline
\end{tabular}

Source: own study based on financial information from Notoria Serwis SA database.

Table 2. Percentage of statistically significant observations of individual accrual based models computed by OLS regression

\begin{tabular}{|l|l|c|}
\hline \multicolumn{1}{|c|}{ Extracted variable } & \multicolumn{1}{|c|}{ Model } & $\begin{array}{c}\text { Statistically significant } \\
\text { observations at the level } \\
\text { of } p \text {-value }=0,05 .\end{array}$ \\
\hline \multirow{2}{*}{ Discretionary accruals $(D A C C)$} & Jones & $44.44 \%$ \\
\cline { 2 - 3 } & Kasznik & $63.89 \%$ \\
\hline \multirow{2}{*}{ Current discretionary accruals $(D C A C C)$} & Dechow, Dichev & $19.44 \%$ \\
\cline { 2 - 3 } & McNichols & $22.22 \%$ \\
\hline
\end{tabular}

Source: own study based on financial information from Notoria Serwis SA database.

create a regression model which is not only the most powerful at predicting or explaining the values of the dependent variable $T A C C$, but also proved to be statistically significant in nearly two-thirds of the considered companies (see Table 1 and Table 2). In general it should be pointed out that a better degree of adjustment to the empirical data is distinguished by models used to extract the entire discretionary accruals $(D A C C)$ than the current discretionary accruals $(D C A C C)$.

\subsection{Descriptive statistics of individual categories of discretionary accruals}

Table 3 presents the descriptive statistics of individual categories of the discretionary accruals which were computed on the basis of the Jones model, the Kasznik model, the Dechow-Dichev model or the McNichols model. An analysis of the empirical research shows that in most cases the discretionary accruals (both $D A C C$ and $D C A C C$ ) took the form of observations with negative values. The conducted research leads also to the conclusion that regardless of the models used for the detection of earnings management. the percentage of positive values of abnormal accruals is similar. This may allow for the presumption that manipulation of financial reports in 
Polish companies belonging to the stock markets WIG20 and mWIG40 was directed towards increasing and reducing the financial results in congruous terms.

Table 3. Descriptive statistics for individual categories of discretionary accruals computed by OLS regression

\begin{tabular}{|l|c|c|c|c|c|c|}
\hline \multicolumn{1}{|c|}{ Model } & Mean value & First quartile & $\begin{array}{c}\text { Second } \\
\text { quartile } \\
\text { (median) }\end{array}$ & $\begin{array}{c}\text { Third } \\
\text { quartile }\end{array}$ & $\begin{array}{c}\text { Positive } \\
\text { observ. }\end{array}$ & $\begin{array}{c}\text { No. } \\
\text { of observ. }\end{array}$ \\
\hline Jones & -0.030 & -0.052 & -0.007 & 0.034 & $43.78 \%$ & \\
\cline { 1 - 5 } Kasznik & -0.031 & -0.042 & -0.004 & 0.030 & $45.44 \%$ & \multirow{2}{*}{603} \\
\cline { 1 - 5 } Dechow, & -0.042 & -0.050 & -0.003 & 0.027 & $45.61 \%$ & \\
\hline Dichev & -0.023 & -0.041 & 0.000 & 0.037 & $48.76 \%$ & \\
\hline
\end{tabular}

Source: own study based on financial information from Notoria Serwis SA database.

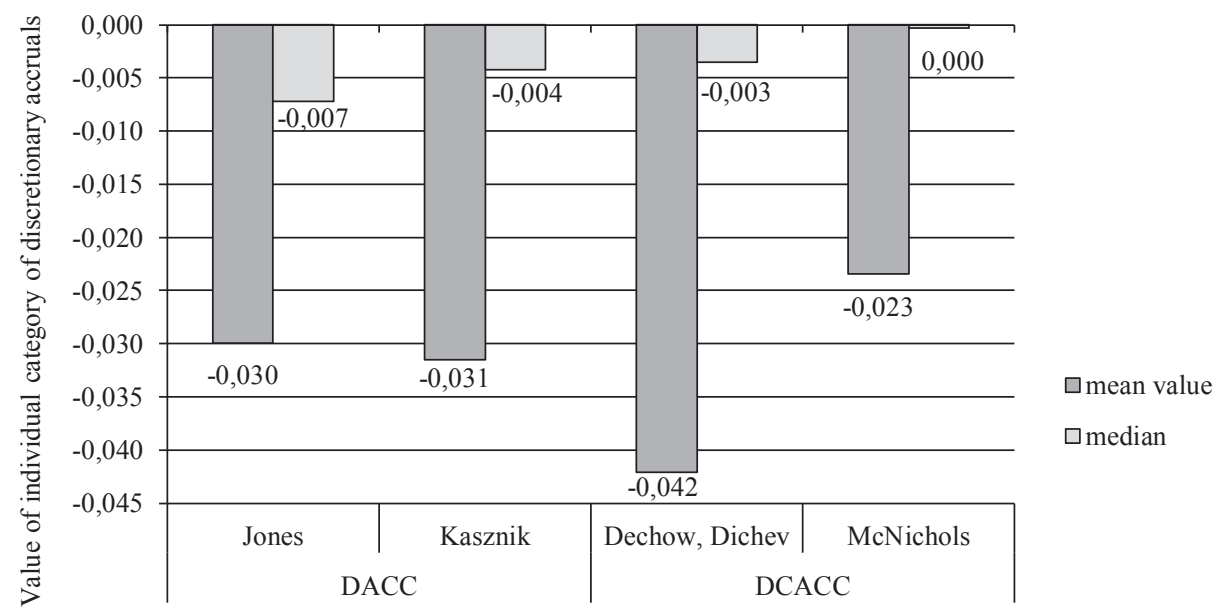

Tested model and category of extracted variable

Fig. 1. The arithmetic mean and the median values of the discretionary accruals coefficients $(D A C C$ and $D C A C C$ ) calculated for companies belonging to the Warsaw Stock Exchange

Source: own study based on financial information from Notoria Serwis SA database.

A special comment should be made on the fact that much larger differences between the mean values of the tested variables were observed in relation to the current discretionary accruals ( $D C A C C$ ) estimated by the Dechow-Dichev model and the McNichols model than to discretionary accruals $(D A C C)$ extracted via the Jones model and the Kasznik model. The distributions of the tested DACC and DCACC 
variables computed by each of the four analyzed models indicate a clear left-sided asymmetric distribution of the scrutinized variables, which is shown in Figure 1.

\subsection{Relationship between differentiated categories of discretionary accruals}

According to the assumptions, the results of the correlation analysis carried out for all the analyzed listed companies indicate that the relations between the same types of discretionary accruals are characterized by very strong or significant power (see Table 4).

Table 4. Relationship between individual categories of discretionary accruals investigated using the Pearson linear correlation coefficient

\begin{tabular}{|l|c|c|c|c|c|}
\hline \multicolumn{1}{|c|}{ Model } & Jones & Kasznik & $\begin{array}{c}\text { Dechow, } \\
\text { Dichev }\end{array}$ & McNichols \\
\cline { 2 - 5 } & $\begin{array}{c}\text { Type } \\
\text { of accruals }\end{array}$ & DACC & DACC & DCACC & DCACC \\
\hline Jones & $D A C C$ & 1 & \multicolumn{2}{c|}{} \\
\hline Kasznik & $D A C C$ & 0.956 & 1 & \multicolumn{2}{c|}{} \\
\hline $\begin{array}{l}\text { Dechow, } \\
\text { Dichev }\end{array}$ & $D C A C C$ & 0.330 & 0.465 & 1 & 1 \\
\hline McNichols & $D C A C C$ & 0.546 & 0.691 & 0.830 & 1 \\
\hline
\end{tabular}

Source: own study based on financial information from Notoria Serwis SA database.

The strength of the mentioned relationship measured by the Pearson's linear correlation coefficient, ranged from 83.0\% (DCACC, calculated by the Dechow-Dichev model and the McNichols model) to $95.6 \%$ (DACC, computed by the Jones model and the Kasznik model). At the same time, relationships between separate categories of discretionary accruals $(D A C C-D C A C C)$ were distinguished by at most moderate strength of correlation, which can be considered an important argument for the simultaneous use of different models used for estimating the earnings management phenomenon.

\section{Conclusions}

Accrual-based earnings management in public companies focuses on the possibility of applying a wide range of accounting practices that allow for distortions in net profit (loss). These activities take into account the varied motives of these manipulations, which usually focus either on providing investors with a sense of security in the capital invested in shares (stocks) by showing the financial standing of the entity 
in a better light than is actually found, or based on low incentives for accounting procedures.

Despite the fact that the numerical findings referring to the value of the reported financial result and the factors shaping it are often verified as part of the financial audits carried out, the phenomenon of earnings management is difficult to unequivocally detect. Namely, researchers and auditors usually have one source of data on the financial standing of an enterprise, which is the financial report of the economic entity after specific interventions of company executives. Hence, the recognition and assessment of changes in individual items composing accruals and the isolation of discretionary accrual, which are the result of subjective accounting choices, not only significantly enhance the predictive value of the operational cash flow statement, but can be seen as a useful tool in the early detection of potential earnings management practices.

The empirical studies carried out in the article showed that among the four regression models commonly quoted in the literature allowing for the extraction of non-discretionary and discretionary accruals, the Kasznik model was characterized by a decidedly above-average goodness-of-fit to the empirical data. This means that the inclusion of operating cash flows into the original version of the Jones model (as an exogenous variable explaining the value of the TACC coefficient) may significantly increase the prognostic value of the analytical models used to separate individual sub-categories of net profit adjustments. However the research shows that econometric models based on operating cash flow are not always characterized by a higher degree of matching the empirical data compared to the original version of the Jones model. This assumption was only met with reference to the previously mentioned Kasznik model. It has not been reflected in the Dechow-Dichev model or the McNichols model. On the other hand, the obtained results of the empirical studies indicate the appropriateness of using different analytical models so that it is possible to separate various categories of discretionary accruals (DACC and DCACC).

Taking into account the limitations of the research problem under consideration, it should be clearly indicated that the presented research results cannot meet the condition of generalization. They are only exemples of reflections on the use of alternative econometric formulas in the analysis of earnings management practices. They contain partial results relating to public companies belonging to WIG20 and mWIG40 and in the longer term should open up to a wider group of tested enterprises. Certainly, these studies are a contribution to further research on tools for examining accrual-based earnings management in the context of the Polish capital market. 


\section{Bibliography}

Arsenijević A., Dukić T., 2017, Creative cash flow reporting, Facta Universitatis, Series: Economics and Organization, University of Niš, vol. 14.

Comporek M., 2018, The relationship between reserves and accruals - with reference to the issue of earnings management in public companies, Financial Sciences, vol. 23, no. 3, Publishing House of Wroclaw University of Economics, Wrocław.

Dechow P.M., Dichev I.D., 2002, The quality of accruals and earnings: the role of accrual estimation errors, The Accounting Review, no. 77(s-1).

Gos W., 2010, Organizacja ksiag rachunkowych na potrzeby sporządzania rachunku przepływów pieniężnych metoda bezpośrednia, Zeszyty Teoretyczne Rachunkowości, t. 56(112), Stowarzyszenie Księgowych w Polsce, Warszawa.

Healy P.M., Wahlen J.M., 1999, A review of the earnings management literature and its implications for standard setting, Accounting Horizons, no. 13(4).

Hosseinimehr S., Nourifard Y., 2014, The persistence of accruals and investment in operating and investment cycle, Accounting and Finance Research, vol. 3, no. 2.

Ijiri, Y., 1975, Theory of Accounting Measurement, Studies in Accounting Research, no. 10.

Jones J., 1991, Earnings management during import relief investigations, Journal of Accounting Research, vol. 29 , no. 2.

Kasznik R., 1999, On the association between voluntary disclosure and earnings management, Journal of Accounting Research, no. 37.

Kutera M., Hołda A., Surdykowska S., 2006, Oszustwa księgowe. Teoria i praktyka, Difin, Warszawa.

McNichols M.F., 2002, Discussion of the quality of accruals and earnings: the role of accrual estimation errors, The Accounting Review, no. 77.

Megan O., Schmidt A., Cotlet B., 2009, The utility of cash-flow statement for Romanian financial statements users during financial crisis, Proceedings of the 5th WSEAS International Conference on Economy and Management Transformation (Volume II).

Micherda B., Szulc M., 2008, Analiza finansowa w badaniu możliwości popetnienia oszustw, Zeszyty Naukowe Uniwersytetu Ekonomicznego w Krakowie, nr 785, Kraków.

Mulford C.W., Comiskey E., 2005, Creative Cash Flow Reporting: Uncovering Sustainable Financial Performance, John Wiley and Sons Inc.

Negrea L., Matis D., Mustata R., 2011, Cash flow reporting and creative accounting, Annals of the University of Oradea. Economic Science, vol. 1, no. 2.

Ostasiewicz S., Rusnak Z., Siedlecka U., 2001, Statystyka. Elementy teorii i zadania, Wydawnictwo Akademii Ekonomicznej we Wrocławiu, Wrocław.

Ronen J., Yaari V., 2008, Earnings Managament, Springer Verlag.

Schilit H., Perler J., 2010, Financial Shenanigans - How to Detect Accounting Gimmicks and Fraud in Financial Reports, third edition, McGraw-Hill, New York.

Schipper K., 1989, Earnings management, Accounting Horizons, vol. 3(4).

Śnieżek E., Wiatr M., 2011, Interpretacja i analiza przepływów pieniężnych, Wolters Kluwer Polska, Warszawa.

\section{WYKORZYSTANIE OPERACYJNYCH PRZEPLYWÓW PIENIĘŻNYCH W ESTYMACJI ZARZĄDZANIA ZYSKIEM}

Streszczenie: Jedną z nadrzędnych analitycznych sfer umożliwiających oszacowanie skali i kierunków księgowego zarządzania zyskiem jest obszar korekt zysku netto, wyodrębnianych w rachunku przepływów pieniężnych sporządzonym metodą pośrednią. Zasadniczym celem artykułu jest wyeksponowanie 
tych modeli regresyjnych służących do pomiaru i oceny zjawiska zarządzania zyskiem, które w swojej postaci uwzględniają przepływy pieniężne z podstawowej działalności przedsiębiorstwa jako istotną zmienną objaśniającą kształtowanie różnic memoriałowych w danym okresie. Zaliczono do nich modele: Jones, Kasznika, Dechow i Dicheva oraz McNichols. W opracowaniu przyjęto, iż atrybut operacyjnych przepływów pieniężnych, pozwalający na eliminację skutków różnych księgowych ujęć takich samych transakcji i zdarzeń gospodarczych, może wzmocnić predykcyjną siłę tychże modeli i stworzyć nową płaszczyznę pomiaru i porównań dokonań podmiotów gospodarczych. Badaniom empirycznym poddano spółki giełdowe przynależące do subindeksów giełdowych: WIG20 i mWIG40, których akcje były przedmiotem obrotu giełdowego przez co najmniej 10 lat w przyjętym horyzoncie odniesienia 1998-2017.

Słowa kluczowe: operacyjne przepływy pieniężne, korekty zysku netto, zarządzanie zyskiem, wynik finansowy, modele regresyjne. 